\section{The dissemination mechanisms of Industry 4.0 knowledge in traditional industrial districts: evidence from Italy}

\author{
Alessandro Pagano, Elisa Carloni, Serena Galvani and \\ Roberta Bocconcelli \\ Department of Economics, Society and Politics, University of Urbino Carlo Bo, \\ Urbino, Italy
}

Mechanisms of Industry 4.0 knowledge

\section{Received 31 December 2019 Revised 15 April 2020 Accepted 28 April 2020}

\begin{abstract}
Purpose - This paper aims to provide a contribution on the diffusion of Industry 4 (I4.0)-related knowledge in industrial districts (IDs). The main goal is to examine the dissemination of I4.0 knowledge, exploring the main mechanisms for its spreading and highlighting the main factors shaping such processes. Focus is on dissemination processes in IDs active in traditional industries, which could represent the "periphery" of I4.0 application context.
\end{abstract}

Design/methodology/approach - The methodology is qualitative. Notably, this paper presents a case study of the Pesaro ID specialized in furniture/woodworking machinery sector. A total of 18 in-depth one-toone interviews have been conducted with relevant informants from a variety of organizations within the cluster: companies, institutions and universities.

Findings - The complexity of I4.0 requires a combination of traditional mechanisms with innovative ones within IDs characterized by the emergence of new players, activities and resources. These changes led to three main evolving patterns: the horizon of I4.0 upgrading shows blurred boundaries in terms of sectors and geographic location, the I4.0 diffusion appears fragmented in terms of initiatives and projects by both firms and institutions and the dissemination of I4.0 knowledge pushes ID firms and institutions to pursue deliberate initiatives leading to innovative forms of "collective" cooperation.

Originality/value - This paper contributes to both theory and practice. From the theoretical point of view, this paper contributes to the literature on innovation in IDs and clusters on two interrelated grounds. First, it provides further research on I4.0 and IDs and clusters. Second, it contributes to the stream of research on knowledge creation and diffusion in IDs and clusters, providing empirically based insights over emerging local learning processes in IDs. Moreover, relevant managerial and policy implications stem from the analysis.

Keywords Innovation, Policy, Industry 4.0, Knowledge diffusion, Industrial districts

Paper type Research paper

\section{Introduction}

Firms agglomeration is a relevant phenomenon for economic and industrial development. Economics and management scholars have examined in depth the features and the evolution of industrial districts (IDs) and clusters, leading to relevant conceptual

(C) Alessandro Pagano, Elisa Carloni, Serena Galvani and Roberta Bocconcelli. Published by Emerald Publishing Limited. This article is published under the Creative Commons Attribution (CC BY 4.0) licence. Anyone may reproduce, distribute, translate and create derivative works of this article (for both commercial and non-commercial purposes), subject to full attribution to the original publication and authors. The full terms of this licence may be seen at http://creativecommons.org/licences/by/4.0/legalcode

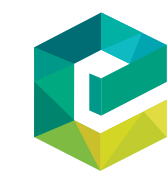

Competitiveness Review: An International Business Journal Vol. 31 No. 1, 2021 pp. $27-53$ 1059-5422 DOI 10.1108/CR-12-2019-0160
Emerald Publishing Limited 
$\mathrm{CR}$ 31,1

developments (Porter, 1998; Lazzeretti et al., 2014). Recently a stronger effort has been placed on a better understanding of the evolution of IDs and clusters (Camuffo and Grandinetti, 2011; Belussi and Sedita, 2012; Fornahl et al., 2015), with a main focus on the changes in their knowledge processes (Alberti and Pizzurno, 2015), and on the opening to outside sources and its effect on local knowledge circulation and exchange (Waxell and Malmberg, 2007; Belussi and Sedita, 2012). Concepts such as "local buzz" and "global pipelines" have been developed and adopted to gain an understanding of these processes (Bathelt et al., 2004). Such changes are strongly affecting IDs active in traditional sectors, which might be less prompt - in terms of business and technical culture - to absorb technological innovations developed elsewhere (Parrilli, 2009; De Marchi et al., 2017).

Another key phenomenon for economic and industrial development is the emergence of the Industry 4.0 (hereafter I4.0) paradigm. It can be viewed as the fore-front of technological and organizational innovations related to the exploitation of current advancements of information technologies (Kagermann et al., 2013; Fitzgerald et al., 2014). The surge of the I4.0 paradigm is pushing academic scholars to explore its diffusion in terms of adoption processes in business firms (Horváth and Szabó, 2019) and its overall impact on companies (Barrett et al., 2015; Arnold et al., 2016; Müller et al., 2018). In-depth empirical analyses of I4.0 diffusion in industrial clusters are still limited. A few insightful recent studies have started to assess whether and how I4.0 approach is diffused within IDs and clusters and whether its technological and organizational underpinnings could match the underlying inter-organizational processes in contemporary industrial clusters (Götz and Jankowska, 2017; Hervas-Oliver et al., 2019). This initial research effort is mainly focused on specific institutional projects - within the policy setting - related to the introduction of I4.0, whereas less emphasis is placed on exploring the variety of knowledge diffusion initiatives promoted - also in autonomy - by both business and non-business actors within the ID, whose combination could generate increased awareness and interest among ID firms. Therefore, the objective of this paper is to provide a contribution on the patterns of diffusion of I4.0 in IDs through the analysis of the main dissemination mechanisms and of the key factors shaping such processes. The main focus is on dissemination processes in IDs active in traditional industries, to analyze whether and how I4.0 approach is diffused in apparently culturally distant business agglomerations, which could represent the "periphery" of I4.0 application context (Eder, 2019). Notably, the research question (RQ) addressed in this paper is the following:

$R Q 1$. How is Industry 4.0-related knowledge spread in IDs active in traditional industries?

Thus, this paper represents a complementary contribution in the emerging research on I4.0 diffusion in IDs (Götz and Jankowska, 2017; Hervas-Oliver et al., 2019), in the light of its focus on the main dissemination mechanisms. This research orientation could provide useful insights to the growing stream of studies on knowledge creation and learning processes in IDs and clusters, placing emphasis on the degree of opening to outside sources of knowledge and the main diffusion mechanisms (Belussi and Sedita, 2012; Balland et al., 2016; Maghssudipour et al., 2020).

To answer this explorative RQ, a qualitative research methodology based on a casestudy approach is adopted. Notably, this paper is focused on the analysis of the furniture/ woodworking machineries ID located in Pesaro in Center Italy. The ID under investigation has been very active in a traditional sector - furniture/mechatronic - and has been greatly impacted by the economic crisis started in 2007-2008, showing a high degree of resilience. In recent years, the cluster has been characterized by various initiatives - both at the firm and 
institutional level - aiming at promoting both technological and organizational upgrading of district firms, with an increasing focus on I4.0 solutions.

The empirical analysis relies on the ARA (Activities - Resources - Actors) model (Håkansson and Snehota, 1995) developed in the business network approach of IMP (industrial marketing and purchasing) group (Håkansson et al., 2009). The ARA framework allows to catch the complexity of the I4.0 knowledge diffusion in our empirical setting, represented by a traditional Italian ID. Notably, traditional Italian IDs have been already acknowledged as having a network-like structure based on a variety of key business relationships among different actors, playing a major role in the local diffusion of innovation (Bocconcelli et al., 2015).

Results show the upgrading in the type of knowledge dissemination mechanisms adopted in the ID. The complexity of I4.0 seems to require a combination of traditional mechanisms, shaped by the existing interaction patterns of the Pesaro ID, with innovative ones, characterized by the emergence of new players, activities and resources. These changes lead to three main evolving patterns:

(1) The horizon of I4.0 upgrading shows blurred boundaries in terms of sectors and geographic location.

(2) The I4.0 diffusion appears fragmented in terms of initiatives and projects by both firms and institutions.

(3) The dissemination of I4.0 knowledge pushes ID firms and institutions to pursue deliberate initiatives leading to innovative forms of "collective" cooperation.

The paper is structured as follows. Section 2 is devoted to the analysis of the literature on knowledge and innovation diffusion in IDs and on the emergence of I4.0 and its impact on firms and IDs. In Section 3, the research objective and methodology are addressed. In Section 4 - after a brief presentation of the historical evolution of the Pesaro ID - the main findings of the empirical research are presented along three main phases of the diffusion and dissemination of I4.0 knowledge:

(1) the pioneering phase;

(2) the dissemination effort; and

(3) the pursue of institutional upgrading.

Section 5 discusses the results of the analysis. Section 6 highlights the main contribution of the study, proposes the future lines of research and outlines the main managerial and policy implications.

\section{Literature background}

2.1 Innovation processes and knowledge exchanges in industrial districts

IDs represent a relevant and complex phenomenon in industrial organization which has been extensively studied in the economics and management field, under various perspectives (Belussi and Pilotti, 2002; Pietrobelli and Rabellotti, 2004; Ingstrup, 2013; Lazzeretti et al., 2014; Hervas-Oliver et al., 2015). The increased interest on agglomerations of firms has spurred many streams of research - in both conceptual and empirical terms - over the themes of IDs, clusters and clustering processes (Speldekamp et al., 2020). Lazzeretti et al. (2014, p. 22) "identify the ID as a particular kind of a more general category of clusters." As the focus of this study is a traditional ID, the existing literature on knowledge creation and innovation in IDs is discussed and integrated with concepts deriving from the recent relevant contributions on clusters. 
$\mathrm{CR}$ 31,1

IDs have been defined by Becattini (1990, p. 39) as "a socio-territorial entity which is characterized by the active presence of both a community of people and a population of firms in a naturally and historically bounded area." IDs are a complex form of industrial organization, whose main elements are the local production network composed by a population of firms; the community of people sharing a feeling of belonging and common identity; and the presence of the so-called "industrial atmosphere" (Marshall, 1920; MolinaMorales, 2002; Belussi and Pilotti, 2002; Boix and Galletto, 2009). IDs are characterized by a division of labor among local firms around a specialized sector, leading to increased efficient exchanges and external economies (Marshall, 1920; Becattini, 1991). Besides firms, IDs are influenced by the behavior of other key actors - such as local institutions, training organizations, business associations and technological centers - providing resources in terms of financial, normative and technical support (Coletti, 2010; Belussi and Sedita, 2012). This complex web of relationships - including both business and non-business actors - is embedded in strong social ties fostering trust and a sense of community in local networks (Dei Ottati, 1994; Belussi and Pilotti, 2002) leading to a shared identity (Staber and Sautter, 2011).

A stream of research on IDs has focused on their evolution processes, leading to mature stages and also to their decline (Belussi and Sedita, 2009; Hervas-Oliver and AlborsGarrigos, 2014; Fornahl et al., 2015). Understanding how and why IDs evolve has been a key concern for ID scholars, who have pointed out two main inter-related patterns: the opening of the ID and the incremental innovation path. Various contributions highlight the incremental opening of the ID system, because of the behavior of ID firms creating business and technological linkages with actors outside the local ID (Becattini and Rullani, 1996; Camuffo and Grandinetti, 2011; Belussi and Sedita, 2012; De Marchi and Grandinetti, 2016). This has led to a reconfiguration of local relationships which are then combined with new emerging partnerships with other firms and organizations, often located in other IDs. This orientation has been pursued mainly by large firms, which have displayed increased autonomy in their strategic behavior. One of the consequences has been the weakening of social ties and the reduced role of key actors, such as institutions and business associations (Camuffo and Grandinetti, 2011). A related pattern shaping the evolution of IDs concerns their technological trajectory, influenced by the type and degree of innovation and by the learning processes in place, generated by the interaction within and outside the ID (Camuffo and Grandinetti, 2011; Belussi and Sedita, 2012; Hervas-Oliver et al., 2018).

One of the advantages possessed by IDs is their efficiency in stimulating the creation of new knowledge and in promoting local learning mechanisms (Belussi and Pilotti, 2002). Thus, IDs may be interpreted as cognitive labs or systems, as they are characterized by a high density of knowledge accumulation, elaboration and circulation by means of various transfer mechanisms, such as inter-organizational and interpersonal relations; observation or artifacts and actions; mobility of human resources; and creation of new ventures (Becattini and Rullani, 1996; Maskell, 2001; Camuffo and Grandinetti, 2011; Grandinetti, 2011). Various studies claim that spatial proximity in existing localized overlapping networks facilitates knowledge sharing and thus innovation in clusters (Belussi and Pilotti, 2002; Carbonara, 2004; Boix and Galletto, 2009; Alberti and Pizzurno, 2015). Local networks function as key vehicles of knowledge transfer and diffusion: being in the right place is necessary, but being in the right network is of utmost importance (Boschma and Ter Wal, 2007).

However, geographical proximity is not enough per se to understand innovation in local industrial networks (Alberti and Pizzurno, 2015). In fact, even if belonging to the same cluster, firms might have a different degree of access to knowledge, depending on other factors than spatial proximity, such as institutional, cognitive, organizational and social 
proximity and absorptive capacity (Cohen and Levinthal, 1990; Giuliani, 2005; Camuffo and Grandinetti, 2011). Innovation is the outcome of the "heterogenous recombination of a broader set of knowledge types" (Alberti and Pizzurno, 2015: 270), i.e. technological, managerial and market knowledge, and thus it should be considered as a synergy of a firm's internal - i.e. absorptive capacity - and external resources - i.e. relational resources (HervasOliver and Albors-Garrigos, 2009).

Interactive learning processes in IDs and clusters are organized in different ways, depending on the tacit or codified nature of knowledge. A distinction is made between the concept of "local buzz" and of "global pipelines": local buzz refers to "the learning processes taking place among actors embedded in a community by just being there," whereas global pipelines concern "the knowledge attained by investing in building channels of communications to selected providers located in outside the local milieu" (Bathelt et al., 2004, p. 31). Recent studies have shown the increasing variety and complexity of learning mechanisms and processes, which rely on a mix of emergent (informal) and deliberate (formal) knowledge structures, implemented locally and/or in connection with actors outside the ID (Belussi and Sedita, 2012). Emerging or informal structures are those activated unintentionally through networking and personal contacts, whereas deliberate or formal structures are those planned, such as R\&D interactions with distant partners (Belussi and Sedita, 2012; Lazzeretti and Capone, 2016).

The literature on knowledge exchange in IDs and clusters has focused on the role of specific actors - the "gatekeepers" - in the local dissemination of knowledge, in light of their "ability to access external knowledge and construct a conversion process which deciphers external knowledge and turns it into something locally understandable and useful" (Hervas-Oliver and Albors-Garrigos, 2014, p. 431). Their role as brokers is concerned with searching for, absorbing and matching internal and external sources of knowledge, and then disseminating the resulting knowledge within the cluster (Giuliani and Bell, 2005; Boschma and Ter Wal, 2007; Morrison, 2008; Hervas-Oliver and Albors-Garrigos, 2014). The role of gatekeeper can be played by leading firms within the cluster (Morrison, 2008; Belussi and Caloffi, 2018) and by institutions, research centers, universities, business associations and knowledge providers that operate as local/global cognitive interfaces (Grandinetti, 2011). Leader firms - more oriented to mediumlong strategic views - tend to introduce more complex innovations within the cluster and to influence the decisions of the local institutional actors (Albino et al., 1999; Corò and Grandinetti, 1999; Boschma and Ter Wal, 2007; Chiarvesio et al., 2010). Knowledge providers and local institutions instead carry on activities to support the ID firms, as they offer support services and at the same time provide innovation opportunities and act as repositories of knowledge. Their role can be described as intermediary agents as they can act as brokers for the development of relationships between district firms and potential external exchange partners (Molina-Morales et al., 2002; Hervas-Oliver et al., 2012; Belso-Martinez et al., 2018). A few studies investigate the role of universities as gatekeepers in IDs (Camuffo and Grandinetti, 2011; Capó-Vicedo et al., 2013). Universities can represent key knowledge providers, being a source of specialized and updated knowledge, thanks to their international research networks' pipelines (Muscio et al., 2012).

Innovation and learning processes in IDs are affected by the growing digitalization of business processes and inter-firm interaction (Biggiero, 2006; Hervas-Oliver et al., 2019). Digitalization questions the dichotomy of local buzz and global pipelines introduced by Bathelt et al. (2004), as buzz has started to appear in distant networks through Internetbased applications, which can be described as a "buzz without being there" (Moodysson, 2008, p. 452). Even if there seems to be a contradiction between IDs and clusters promoting localized learning and new technologies enabling worldwide dispersion of activities, it has 
$\mathrm{CR}$ 31,1

been argued that these two patterns are not exclusive: IDs and clusters are of special importance as they could provide mechanisms facilitating knowledge development and dissemination, representing thus the possible answer to many challenges brought up by digitalization (Götz and Jankowska, 2017). Recent contributions highlight that the path toward digitalization in IDs and clusters could be affected by the impact of introduction of I4.0-related knowledge and technologies, considered as a "disruptive innovation" (HervasOliver et al., 2018). The next section will explore the nature of I4.0 technologies and the recent contributions in the literature on I4.0 in IDs and clusters.

\subsection{Emergence of Industry 4.0}

In the contemporary business environment, I4.0 has become a buzzword. Managers and entrepreneurs are investing in I4.0 and factories are becoming "smart factories." The term "Industry 4.0" was first used by the German government in 2011, when Kagermann and colleagues wrote an article about high-tech strategies to be applied in the country by 2020. In 2013, the "Industry 4.0 manifesto" was diffused by the German National Academy of Science and Engineering (Kagermann et al., 2013). The concept of I4.0 "is often referred to as the fourth industrial revolution and embraces a set of technological advances that are having a high impact in the current industrial landscape" (Pereira and Romero, 2017, p. 1208).

The improvements that a company can achieve with the introduction of I4.0 technologies are mainly three: "digitization of production-information systems for management and production planning, automation-systems for data acquisition from the production lines and using machines [and] linking manufacturing sites in a comprehensive supply chain" (Roblek et al., 2016, p. 2).

Several studies investigated the achieved level of adoption of I4.0 technologies by companies (Brancati and Maresca, 2017; Digital 360 Research - IBM, 2017; Brozzi et al., 2018), showing a substantial level of diffusion, even if a higher pace of adoption is expected in the next years and, predictably, the rate of adoption in large companies will be greater than the one in smaller firms (Brancati and Maresca, 2017). However, despite an increasing rate of adoption of I4.0 technologies, these studies show a general lack of awareness about the potential business value they can generate, particularly by small firms (Osservatorio Industria 4.0, 2018; AmCham (American Chamber of Commerce in Italy), 2018). What is still missed by firms is a complete perception of the possible directions toward which the I4.0 innovation can lead them. Companies understand the relevance of the I4.0 change, but they are still not able to foresee its possible future developments.

Indeed, I4.0, as a set of new technologies, does not constitute a disruptive change per se; nonetheless, the use of I4.0 technologies implies a disruptive change in firms that is related to the set of external and internal managerial implications to achieve major business improvements (Hervas-Oliver et al., 2019). Internal changes refer mainly to changes in operations, production lines, technical and digital tools (Frank et al., 2019), whereas external changes concern changes in relationships with suppliers and customers, the integration of new subjects as consultants or KIBS and the changing roles of firms in their networks (Hein et al., 2019; Sklyar et al., 2019a, 2019b).

In the context of IDs, it is challenging to assess the future implications of I4.0, partially because adopting disruptive innovations in IDs is highly complex, because of the nature of IDs, which tend to innovate incrementally. The literature on this topic is still limited. HervasOliver et al. (2019) analyze the successful implementation of a place-based project of I4.0 in the Castellon ceramic tile district. This study underlines a bottom-up approach of policies, based on the involvement of relevant stakeholders and collective actors in decisional processes, to generate spillovers and I4.0 innovation at the regional level. On the same 
wavelength is the work of Götz and Jankowska (2017) on formal clusters and I4.0 industrial transformation, where it is argued that the knowledge diffusion mechanisms in clusters could facilitate the upgrading in firms and institutions. Both studies look at empirical settings where institutional actors play a leading role in diffusing I4.0 knowledge in IDs and local clusters. It could be argued that this initial stimulating research effort could be enriched by further empirical evidence over the variety of knowledge dissemination mechanisms - related to I4.0 technologies - involving both business and non-business actors in IDs.

Mechanisms of Industry 4.0 knowledge

\section{Research objectives and methodology}

This research aims to investigate the process of diffusion of I4.0 related-knowledge within a traditional Italian ID. The explorative nature of the outlined RQ that aims to unveil the process of spreading of I4.0-related knowledge within a particular context (i.e. an ID) required the collection of rich empirical data around that cluster and, therefore, the use of a qualitative methodology.

Notably, this paper applies a single case study methodology (Yin, 2003) of an industrial cluster located in Center Italy, the Pesaro ID, specialized in the furniture and woodworking machinery sector. Thus, consistent with extant work on clusters and IDs, the unit of analysis is contextualized as the ID (Mitchell et al., 2014). The main advantage of such methodology is local groundedness which helps to overcome limitations of quantitative analysis, uncovering latent and basic social and institutional dynamics that underpin patterns of interaction (Samarra and Belussi, 2006; Wolfe and Gertler, 2004). Moreover, case study method has been already proven effective in the analysis of the specific issue under investigation in this research (Belussi and Sedita, 2012; Hervas-Oliver et al., 2019).

The cluster has been chosen according to two distinct criteria:

(1) its specialization in a traditional industrial sector - furniture/mechatronics; and

(2) available evidence of undergoing projects related to I4.0 implemented by both local institutions and businesses.

The empirical study was designed to have an overview as complete as possible on the I4.0 related-knowledge diffusion within the cluster and different sources of data have been used consistently. The first data source was one-to-one, in-depth semi-structured open-ended interviews (Cavana et al., 2001). To select interviewees, we compiled a list of companies, institutions - universities, industry associations - professional consultants, based on local and public industry documents and on two interviews with a key informant and with a representative of the local Industrial Association. Within these categories, we chose potential participants based on the preliminary information collected and asked them to participate to the interview process. We completed 18 in-depth interviews during a fourmonth period from September 2019 to January 2020. In some cases, for the more relevant companies/organizations, we interviewed different people in different positions to triangulate data and to have different perspectives (see Table 1). The interviews lasted for approximately $1 \mathrm{~h}$ each, and were, in some cases, supplemented by written notes of the interviewer. All the interviews were recorded and transcribed verbatim.

A second important data source was represented by the mapping of what we called the knowledge dissemination "initiatives." These include all the activities prompted by different institutions (i.e. Region, universities, business associations, technology centers) and businesses to widen and circulate information on I4.0 related-knowledge. Six typologies of dissemination initiatives have emerged: workshops and conferences; training courses; R\&D projects; non-research business partnerships; industrial $\mathrm{PhD}$ scholarships; and public 


\begin{tabular}{|c|c|c|}
\hline \multirow{4}{*}{$\begin{array}{l}\text { CR } \\
31,1\end{array}$} & Company/organization/institution & Interviewees \\
\hline & ACCENTURE & Senior Manager \\
\hline & $\begin{array}{l}\text { Consultancy } \\
B E R L O N I B A G N O\end{array}$ & Accountino Manager \\
\hline & Furniture & \\
\hline \multirow{16}{*}{34} & BIESSE & Innovation Manager \\
\hline & Mechatronics/woodworking machineries & Service Marketing Assistant \\
\hline & CLUSTER MARCHE & $\begin{array}{l}\text { Sophia Ambassador } \\
\text { Cluster and Project Manager }\end{array}$ \\
\hline & Regional institution & \\
\hline & CONFINDUSTRIA & Fiscal Financial Representative \\
\hline & COSMOB & General Manager \\
\hline & Furniture Consortium & Post-Doc Industrial Researcher (from University of Urbino) \\
\hline & $I M A B$ & HR and Organization Manager \\
\hline & Furniture & Technical Area Manager \\
\hline & LCMOBILI & Purchasing and Production Director \\
\hline & $\begin{array}{l}\text { Furniture } \\
\text { UNIVERSITY OF URBINO }\end{array}$ & $\begin{array}{l}\text { Professor of Quality Management - Tutor for a post-doc } \\
\text { industrial position in I } 4.0\end{array}$ \\
\hline & & $\begin{array}{l}\text { Professor of Business Management - Supervisor of Industrial } \\
\text { PhD student (Biesse) }\end{array}$ \\
\hline & & Professor of Computer Science-Representative in the \\
\hline & & Stakeholders' table for INNOPROVEMENT project \\
\hline & & $\begin{array}{l}\text { Professor of Computer Science - Expert in Machine learning } \\
\text { and IoT }\end{array}$ \\
\hline & & KTO Representative \\
\hline 1. & SINERGIA CONSULENZE & Founder and Senior Partner \\
\hline Interviewees' profile & Consultancy & \\
\hline
\end{tabular}

tenders. This classification is based on categories used in the ID/cluster literature (Alberti and Pizzurno, 2015; Calignano et al., 2018). Each initiative has been coded in terms of promoters, duration, membership, content and project horizon.

Dissemination initiatives were identified through official websites of the European Union, of the Italian Government, of Regional Institutions - such as Marche Region and Cluster Marche - of local actors - firms, technology centers and universities. Also, a search through newspapers articles, annual reports from local knowledge providers, projects presentations and reports and regional guidelines released from the Regional Government has been used to map the initiatives.

Throughout interviews and secondary sources, we have been able to collect and map a total of 83 dissemination initiatives (see Table 2). Each dissemination activity has been classified according to different parameters (i.e. organizers and promoters, year, participants, content, level of the initiative, speakers and follow-up). This mapping activity allowed to have a broad picture of the process of diffusion initiatives of I4.0 knowledge in the ID.

In-depth interviews with cluster actors, the mapping of the knowledge diffusion initiatives, along with desk-top reviews of secondary data (previous studies, media reports, official documents and internal reports, official statistical data, websites and newspapers' interviews) allowed us to monitor the process of I4.0 knowledge diffusion over time in the 2015-2019 period and to introduce in the study the process perspective that is crucial to address the "how" nature of the RQ (Halinen and Törnroos, 2005). All these sources enhance 
data reliability, because of both the composition of data sources and the relevant experience of the interviewees over the issue under investigation. We based interview content on theoretical considerations, and asked all interviewees about their role in the cluster, and their perception of knowledge flows and exchange between actors within the cluster. All data sources have been used in generating questions to be submitted to our interviewees and to triangulate information and responses.

In addition, for some interviewed people, we also asked to draw network pictures. Network pictures are graphical representation of the network of actors and relationships around a specific theme (Ramos and Ford, 2011). This research tool has been proven particularly useful when dealing with a novel theme such as I4.0 and when different people within an organization are interviewed (Öberg, 2012).

Data analysis followed a systematic combining, i.e. we adopted an abductive approach (Dubois and Gadde, 2002) in line with the explorative nature of the case research, based on logic of investigation aimed at matching recursively theory and empirical observations. Systematic combining is suitable for studying a new or under-researched phenomenon while also paying attention to existing theories around the topic (La Rocca et al., 2017). Finally, we coded the analysis into common themes in relation to the diffusion of I4.0 knowledge to link again empirical observations to theoretical knowledge. Through this process, we consistently considered the question of what exists in extant literature and what is novel, with a view to integrating appropriate literature. In doing this, we relied on the ARA model developed in the IMP approach (Håkansson and Snehota, 1995) as the main analytical framework that helped us to frame the discussion around these three layers. In our perspective, ARA model is a powerful analytical tool in the data analysis and interpretation because it allows to unveil "hidden network processes" (Ingemansson Havenvid et al., 2016, p. 100) and the interactions and relationships between relevant actors, activities and resources that are considered in the IMP perspective the actual fuel of innovation networks (Rubach et al., 2017). Italian IDs have been recognized as network-like structures based on long-lasting business relationships, notably in the context of learning and knowledge diffusion (Bocconcelli et al., 2015). The case has been presented in three different temporal phases (Quintens and Matthyssens, 2010).

\section{Empirical findings}

In this section, the main empirical findings are discussed. In the following section, we will provide a brief description of the evolution of the Pesaro ID. Afterwards, the trajectory of diffusion and dissemination of I4.0 related-knowledge is developed along the three main phases.

\begin{tabular}{|c|c|c|c|c|c|c|c|}
\hline $\begin{array}{l}\text { Typology } \\
\text { Year }\end{array}$ & $\begin{array}{c}\text { Workshops and } \\
\text { conferences }\end{array}$ & $\begin{array}{l}\text { Training } \\
\text { courses }\end{array}$ & $\begin{array}{l}\text { R\&D } \\
\text { projects }\end{array}$ & $\begin{array}{l}\text { Non-research business } \\
\text { partnerships }\end{array}$ & $\begin{array}{l}\text { Industrial } \mathrm{PhD} \\
\text { scholarships }\end{array}$ & $\begin{array}{l}\text { Public } \\
\text { tenders }\end{array}$ & \\
\hline 2014 & 1 & 0 & 0 & 1 & 0 & 0 & \\
\hline 2015 & 0 & 0 & 0 & 2 & 1 & 0 & \\
\hline 2016 & 2 & 1 & 3 & 3 & 0 & 0 & \\
\hline 2017 & 13 & 1 & 0 & 7 & 0 & 1 & S \\
\hline 2018 & 13 & 5 & 4 & 4 & 1 & 1 & Mapping of the \\
\hline \multirow[t]{2}{*}{2019} & 15 & 0 & 0 & 3 & 1 & 0 & dissemination \\
\hline & 44 & 7 & 7 & 20 & 3 & 2 & activities \\
\hline
\end{tabular}


$\mathrm{CR}$ 31,1

\subsection{Evolution of the Pesaro industrial districts}

This study is centered on the Pesaro ID, located in Center Italy in the Marche Region and belonging to Pesaro-Urbino province. The growth path of the Pesaro district reflects the traditional concept of ID given by literature, as it derives from the proximity of firms in the same and contiguous sector that start to build a network of relationships. Historically, the ID arose in the second postwar period by the appearance of the first furniture firms. Between the 50s and the $60 \mathrm{~s}$, a great growth followed. The first firms to populate the district were mainly small furniture-maker artisans. Only in the late 60s, the local production of woodworking machinery originated in the same location and, from that point on, the two sectors grew together as a whole ID (Musso, 2000). The following years witnessed a constant development of the $\mathrm{ID}$, with the entrance of new firms and the enlargement of the existing ones, also thanks to a series of mergers and acquisitions by the leading furniture and mechanical companies. In the 2000s, the Pesaro district was already one of the main Italian production sites for the wood furniture sector and the $35 \%$ of the local economy was implemented around the furniture sector (Bocconcelli, 2004). Along with the growth of the economic actors in the ID, new institutional actors have been set up to support the flourishing local wood furniture sector. In 1983, the specialized technology center COSMOB was established as a joint initiative of local public bodies, business associations and firms, with the aim of helping local firms to gain competitiveness through the offering of technological services, innovation and research solutions. The district has notably evolved in time, showing a great dynamism and adaptation capability. The economic crisis of 2007/2008 hit hard the economy of the ID until nearly 2010/2011 and led to a significant decrease in the production and turnover. Some well-known companies have experienced crises - as Berloni Furniture and Febal, whereas other companies have grown substantially, such as IMAB. Many district SMEs suffered heavily in this period. However, the overall reaction of the local companies has been positive and, since 2014, they have been improving their performance, especially thanks to the implementation of product diversification (De Michele and Foresti, 2019). The exporting rate has experienced a great growth from 2009 on, achieving $€ 453 \mathrm{~m}$ in 2017 (Intesa Sanpaolo, 2018). In 2018, the Foundation Cluster Marche was established with the support of the Regional Government and the involvement of local leading manufacturing and service firms, to upgrade the local technological and managerial competences. In the Pesaro ID, we can identify some leading firms, which represent a focal point for all the districts in terms of innovation and growth. Among them, we can consider Biesse for the mechatronic sector (De Michele and Foresti, 2019), and IMAB and Scavolini for the furniture one. Already in the 20142015 period, the ID experienced a first wave of digitalization projects, in line with the global trends (Fitzgerald et al., 2014). Nevertheless, the digital change has been pulled primarily by the local leading firms, which invested on digital infrastructures in those years, whereas SMEs have started gradually to follow the same path only in the recent years, implementing their first digital projects (Intesa Sanpaolo, 2018).

Notwithstanding the overall resilience of the ID while facing the economic crisis and the market changes, the degree of cooperation and sense of belonging have decreased in the recent period. Both mechanical and furniture firms have been pursuing more autonomous technological and marketing strategies outside the ID horizon, while both local large and small firms have gradually reduced their involvement and commitment in local business associations and in collective projects.

\subsection{Trajectory of diffusion and dissemination of Industry 4.0 knowledge}

4.2.1 Pioneering phase. Knowledge over I4.0 in the ID has been first introduced in the years 2015-2016 through the effort of a few local pioneers - mainly large firms, knowledge providers and universities. 
Biesse has started to discuss about I4.0 with one of its key consulting partners Accenture - already involved in other innovative projects. Indeed, Accenture accumulated knowledge about I4.0 technologies and in particular internet of things (IoT) applications before cooperating with Biesse, even if in different business sectors. The Biesse CEO Assistant for Innovation underlines the leading role of Biesse in approaching I4.0, at least in the mechanical sector: "We have been absolutely the first one, the others [competitors] followed us after one or even two years." Biesse launched the project SOPHIA - an IoT project started in 2016 - which, thanks to the installation of sensors in the machineries, allows to receive data about their performance and functioning from customers worldwide. For the design of SOPHIA project, some key competences were already available internally:

There is no discontinuity, meaning that Biesse invested in internal digitalization for years. In the context of I4.0, Biesse found something already existing that could exactly be part of the stream, the trend of I4.0 [...]. Digitization and automation are continuous processes in the company, the real discontinuity of I4.0 is the IoT technology (Innovation Manager - Biesse).

Other local firms - not belonging to the furniture/woodworking cluster - have started early on with I4.0 projects. Benelli Armi - active in the gun sector - approached I4.0 in 2016, when the Plant Manager took part into a study tour in Stuttgart to learn more about the I4.0 industrial model (Fabbrica Futuro, 2018). Benelli Armi started investing in I4.0, especially through the expansion of the industrial plant with a space entirely dedicated to I4.0 technologies for the completely automated material handling: it hosts AGV, beacon and cobots (StartUp Grind, 2018). Another key local firm - not belonging to the furniture ID - is Schnell, which implemented I4.0 technologies already in 2016. The company invested in the adoption of a robot called APPS with a supporting role in the production line. In the same year, Schnell contacted the Department of Computer Science of the University of Urbino:

[ . . ] just to know more about the opportunities that could stem from I4.0 technologies. [...] They decided to contact us after they had known about Biesse and SOPHIA project. They were curious about the possible applications in their sector. This first contact did not develop further. But I know that some of our students have been hired in Schnell (Professor of Computer Science Expert in Machine learning and IoT - UniUrb).

The dynamism of these companies over I4.0 trajectory has become visible in the local ID through the press and the local business association - and other companies have started to monitor and follow their evolution. In particular, Benelli Armi has been very open for organizing business meetings and visits - involving local institutions and companies - to its plant. In addition to these high-tech companies, the two local universities based in Ancona and Urbino have started R\&D projects and courses on I4.0-related themes. The Marche Polytechnic University (Ancona) undertook various research activities and analysis concerning I4.0 in this early phase. This is the case of research and teaching activities in the Engineering Department of the University. The University of Urbino instead - more focused on social sciences and humanities - began in this phase to establish only some contacts with local firms concerning digitalization with the contribution of researchers belonging to the Computer Science Department. The University of Urbino in this phase lacked an ad hoc strategy with regard to I4.0 collaboration with local firms. The only formal initiative in this phase was the launch of an industrial $\mathrm{PhD}$ on the themes of I4.0 by the Department of Economics with COSMOB.

The recognition of the potential positive impact of I4.0-related technologies pushed some key local knowledge providers and technological centers to undertake activities to increase their ability to assess and exploit these new technological opportunities. This is the case of COSMOB, a technology center operating at international level, dedicated to the furniture sector. COSMOB has been aware of the importance of research on these themes already since 2015-

Mechanisms of Industry 4.0 knowledge 
$\mathrm{CR}$ 31,1

2016 and undertook different initiatives. It participated in a Regional call on Made in Italy and Innovation, not explicitly addressing I4.0, but that paved the way to these themes, involving more than 40 cluster firms. Concurrently, COSMOB financed the previously mentioned $\mathrm{PhD}$ position on Additive Manufacturing in collaboration with the Department of Economics of the University of Urbino. Sinergia - a local consulting company active both on management and on IT consulting - became interested in I4.0 in the same years through a business trip to Germany with Benelli Armi. This initiative made them aware about the need of promoting aggregation and collaboration with other types of institutions - i.e. universities and firms - to address these disrupting themes: "We saw synergies with local universities and started to work with them in some specific areas, such as Artificial Intelligence, Robotics, Vision-Based Systems" (Founder and Senior Partner - Sinergia).

Therefore, in this phase, the pioneer companies and organizations have become increasingly aware of the future impact and relevance of I4.0, even though they still did not have a clear plan over the selection and adoption of I4.0-related knowledge and technologies in their business processes, already implementing digital solutions. Digitalization - in combination with automation processes - has been undertaken also by some other key local furniture producers, such as Scavolini and FAB. The local universities, instead, developed knowledge about I4.0 technologies building on their previous research projects and their extensive network of international collaborations.

4.2.2 Dissemination effort. The approval of the "National plan on Industry 4.02017 2020" by the Italian Ministry of Economic Development, placed I4.0 at the center of the national debate on industrial policies. The plan allowed for high tax benefits for firms undertaking investments on I4.0 technologies. This opportunity raises nation-wide interest for I4.0 by industrial companies. Pesaro ID companies started considering the adoption of these technologies, mainly to enjoy the tax incentives.

Local institutions instead took action to apply for financial resources for the implementation of projects and initiatives - such as the establishment of digital innovation hubs (DIHs) and competence centers - whose goal is the promotion and assistance over I4.0 projects toward local companies. Local institutions and business associations undertook various initiatives to promote visibility to the government plan and to diffuse knowledge about I4.0 technologies. On the one hand, various workshops and seminars have been held, involving local and national experts on I4.0. At the regional level, the formal cluster Cluster Marche - played a key role as promoter and organizer of labs and projects. In various events, local universities have been involved and this has allowed for establishing initial contacts among local ID firms and the universities' departments more active on I4.0. Also, the Industrial Business Association promoted formal and informal initiatives to involve firms in I4.0 and stimulate awareness on these topics.

In addition, ad hoc training courses have been organized to support companies in becoming aware of the challenges related to the adoption of I4.0. The local Industrial Business Association organized a course in collaboration with the School of Management from the Polytechnic of Milan, previously involved in a national roadshow by the National Federation of Industrial Companies. The course aimed at improving the understanding of the potential of I4.0 and at providing concrete tools for firms to increase the efficiency of production processes and systems. The course involved firms from the mechanical sector belonging to the district, as well as local knowledge providers, and aimed to provide an overall picture of both technological and managerial challenges related to I4.0. Also, the Marche Polytechnic University organized a course on I4.0 based on an interdisciplinary approach for both students and practitioners. The University of Urbino organized a conference and a roundtable to discuss with local academics, 
businesses and business associations how to fully exploit the opportunities of I4.0. In addition, the university organized a Summer School in Project Management, having an impact on local companies active in digitalization processes. The HR and Organization Manager of IMAB reports that:

[...] taking part to the Summer School in Project Management had a concrete impact on the company as it made us aware over the upgrading of the digital management of processes.

The local pioneering firms further developed their path oriented toward I4.0 approach. Mechanisms of Industry 4.0 knowledge Biesse continued the implementation of the key project - SOPHIA. During the second phase of the project, Biesse started spreading knowledge about SOPHIA through international trade fairs. The further implementation of SOPHIA made Biesse more aware of the implications of some I4.0 technologies - such as IoT, Sensoring and Big Data - and, as a result, it launched an industrial $\mathrm{PhD}$ project in collaboration with the Department of Economics of the University of Urbino. The project started in 2018 and concerned applied research on I4.0 and servitization. For the development of SOPHIA platform, other research institutions have been involved, such as the Marche Polytechnic University and the Polytechnic University of Milan. These collaborations played a major role in "acquiring competences in the phase of technical implementation of the project and in developing concrete ideas" (Innovation Manager - Biesse).

COSMOB started specific projects, such as the FabLab, a digital manufacturing laboratory, with the aim of creating a connection between I4.0 enabling technologies and the local technical know-how. The FabLab is defined as:

[...] the innovative part of the technological center and has been used as a tool to involve local businesses through the provision of services such as 3D printing and laser cutting (Post-Doc Industrial Researcher - University of Urbino/COSMOB).

Sinergia Consulting has strengthened its collaboration with the Marche Polytechnic University aiming to develop applied knowledge complementary to the core scientific and technological capabilities held by the university. Sinergia grasped the need to "integrate existing competences and to encourage skill transfer from the university" (Founder and Senior Partner). In this sense, they started an industrial $\mathrm{PhD}$ scholarship in collaboration with the Marche Polytechnic University to address I4.0 and artificial intelligence (AI).

In addition to the ID pioneers, in this phase, other local furniture companies have started specific projects concerning I4.0-related technologies (see Table 3).

A common feature of these projects is the emphasis on digitalization of production and, in some cases, there have been attempts to integrate products with I4.0 technologies. The main sources of stimuli have been the suppliers of process technologies and the IT partners, based both locally and outside the district. In most cases, the partnership for the development of an I4.0 project came from previous partnerships with the software house or consultant on other topics. All the firms involved in I4.0 projects in the ID are some of the major representative firms in the district, such as IMAB, FAB and Scavolini. However, for these ID firms, even the larger ones, the adoption of I4.0 technologies represented a difficult and complex challenge. Other relevant ID firms have not invested thus far in I4.0 projects, such as Berloni Bagno, because of the scarcity of resources and the negative perception of the potential advantages offered by such technologies.

The emergence of awareness about I4.0 and the initial attempts to launch I4.0 projects have pushed local institutions and business associations to plan and implement the first monitoring activities. At the regional level, Cluster Marche has recently taken part in Osservatorio 4.0, a regional committee composed of business associations, trade unions and 
CR
31,1

40

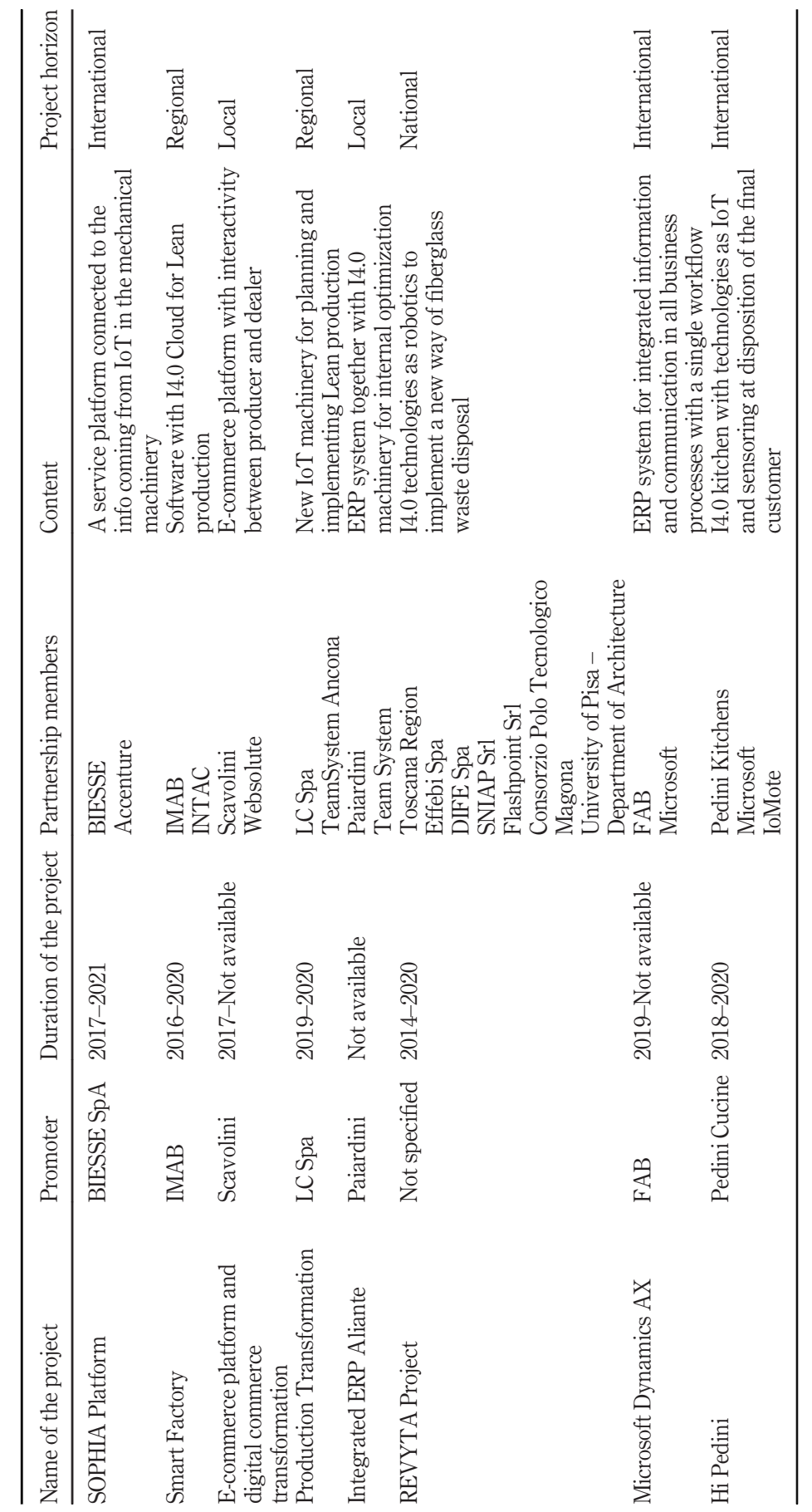

Table 3.

Main I4.0 projects promoted by ID firms 
universities, with the aim of supporting regional intervention and to acquire data to identify the main obstacles for the development and diffusion of I4.0, together with appropriate solutions to better allocate resources through regional industrial policies.

4.2.3 Pursuance of institutional upgrading. The more recent period is characterized by a stronger effort by regional institutions in providing a framework for further promoting and supporting the development of I4.0 projects in local companies, notably in SMEs. The Regional Government becomes aware that the complexity of I4.0 requires stronger coordination. This effort is based on various specific policy measures:

Mechanisms of Industry 4.0 knowledge

- the establishment of DIHs and competence centers;

- the financing of advanced projects proposed by local companies; and

- the active promotion of cooperation between firms and universities, mainly through industrial $\mathrm{PhD}$ projects and multilateral $\mathrm{R} \& \mathrm{D}$ projects.

The stronger effort by the Regional Government has received a mixed feedback by local institutions and companies. On the one hand, the financial support has been welcomed in the light of the required investment scale for implementing I4.0 projects. On the other hand, the unresolved fragmentation of coordination activities over I4.0 themes is perceived as a negative factor for the effectiveness of the limited resources for knowledge dissemination and for promoting the awareness of the local late-comer firms, which might have difficulties in choosing the most appropriate institutional and business partners.

The upgrading also took place through the establishment of the Regional DIHs, which has been planned during the previous phase when the regional Industrial Association and the regional Cluster Marche prompted a feasibility study for the creation of a digital innovation center in the Marche Region and won a European Call within Horizon 2020. DIHs should represent the main "gateway" to I4.0 for local companies. Their aim is creating a network of "territorial innovation actors" to strengthen the level of knowledge and awareness of the opportunities offered by digitalization and I4.0 and offer consultancy, mentoring, training and assistance services for I4.0.

In addition to the upgrading of the regional and local institutional framework, local firms show an increasing propensity to create more stable and formal networks to undertake I4.0 projects. On the one hand, some of the local cluster firms are involved in formal collaborative projects promoted by the Regional Government. This is the case of the regional platform aimed to create a laboratory of excellence to encourage collaboration between businesses and universities on I4.0. Another project started in 2018 is INNOPROVEMENT, where a working group - which includes the cluster firm IMAB and the universities of the Marche Region - on I4.0 has been created. The representative of the Urbino University stated:

My feeling is that there is a lot of work to do in order to address the right policies for SMEs. The main difficulties are linked to put together the objectives of the larger firms and those of the SMEs. I believe that Universities will have a major role in this (Professor of Computer Science Representative in the Stakeholders' table for INNOPROVEMENT project).

On the other hand, local active firms pursue aggregations to combine complementary resources and capabilities. This is the case of Sinergia being an active member of Overlux, a formal network including local firms - also academic spin-off firms from local universities and companies based outside the ID. This network of companies aims at leading businesses toward I4.0 through the implementation of innovative solutions in IoT.

An emerging dissemination pattern is the "Open Factory" approach, after the recognition by some of the key actors - the Industrial Business Association and the Cluster Marche - of the effectiveness of initiatives organized in and by innovative companies active in I4.0 
$\mathrm{CR}$ 31,1

projects. Cluster Marche started promoting this mode of knowledge exchange after experiences with other partner formal clusters in Northern Italy. Promoting direct contact on site with front-runner firms is perceived as a tool for pursuing knowledge contamination and attract furniture producers and small firms having limited IT and technological capabilities. Firms such as Benelli Armi - even though not active in the furniture sector have been keen on opening their offices and plants, also for a shared sense of belonging to the local territory. These initiatives - proposed after a careful planning by these collective actors - in various cases have prompted informal cooperations among participants, which have been monitored in their evolution.

\section{Discussion of results}

This section attempts to provide an answer to the RQ stated in the introduction. First, it summarizes and discusses the evolution of I4.0 knowledge dissemination along the various phases, shown in the timeline in Figure 1. Then, it examines more in depth the dissemination process using the ARA framework and focusing on actors, activities and resources. Finally, it provides a synthesis of the distinctive dissemination patterns emerging from the empirical analysis.

In the "pioneering phase," knowledge about I4.0 has been introduced through the explorative attitude of some key local players, which have autonomously established external pipelines (Bathelt et al., 2004) and gained incremental awareness about the complexity and the possible benefits of I4.0 technologies in the medium-long term. Formal and informal interactions have been carried out with other actors - in Italy and abroad more skilled about the development of I4.0 technologies, which represent a body of knowledge to a large extent "exogenous" (Albino et al., 1999) to the Pesaro ID. As soon as the tax incentives have been publicly announced, a variety of ID actors - firms, institutions, IT suppliers and knowledge brokers - have become interested in understanding the implications of I4.0 upgrading. Since then, various types of initiatives for knowledge diffusion have been set up by institutions, business associations and knowledge providers, with the involvement of local and nationally based universities and technical experts. The

Figure 1.

Timeline of I4.0 knowledge dissemination along the three phases

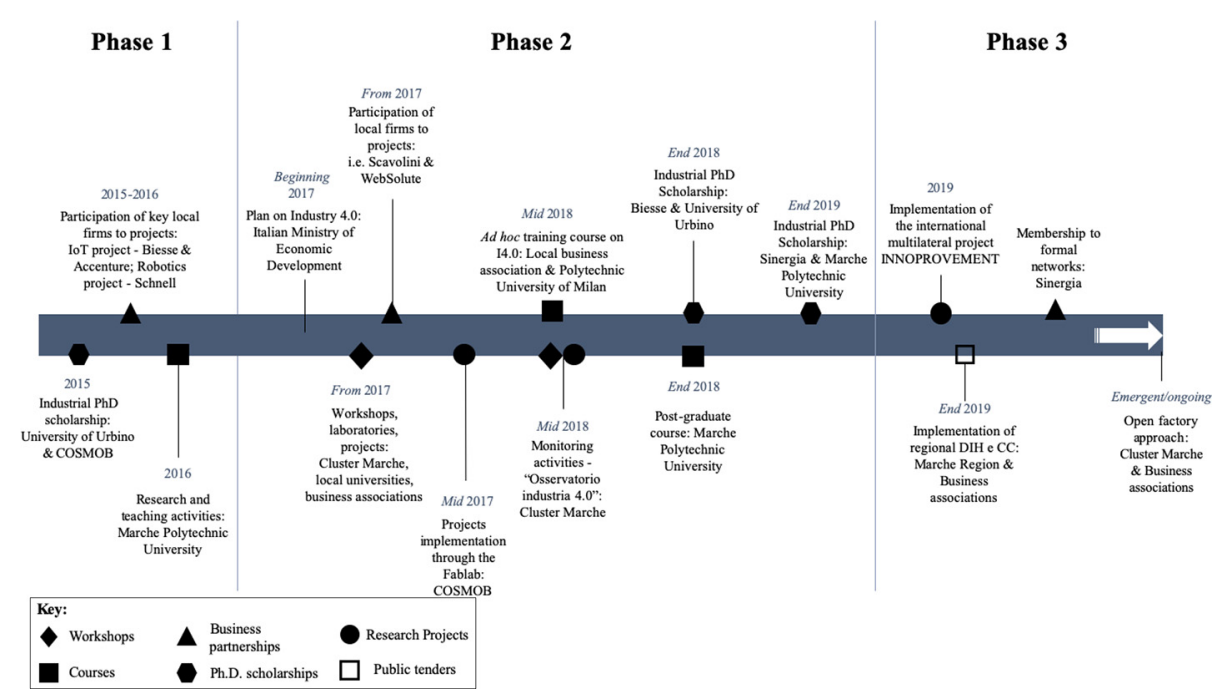


main goal was stimulating the awareness of local firms about I4.0 and accelerating the involvement of local businesses in projects related to I4.0 technologies. After this phase showing a remarkable dissemination effort, a more deliberate approach emerges among both institutions and key players (Belussi and Sedita, 2012; Lazzeretti and Capone, 2016). The Regional Government supports the implementation of DIHs linked to the main local business associations to provide "interfacing" resources to support local firms in undertaking I4.0 projects. The most active knowledge providers establish formal networks involving local and nationally based firms and universities - to integrate and consolidate complementary knowledge and capabilities and to undertake complex R\&D projects related to I4.0. In the meanwhile, the local collective actors - business associations and formal clusters - promote an "Open Factory" approach to disseminate knowledge about I4.0 and thus stimulate contamination and emulation by local firms.

The diffusion of I4.0 knowledge in the ID of Pesaro could be better understood discussing in more depth the behavior of key actors, the nature of activities carried out and the relevant resources at stake in the process, following the ARA model framework (Håkansson and Snehota, 1995). It could be argued that the diffusion of I4.0 knowledge in the Pesaro ID has been characterized by a combination of "traditional" and innovative dissemination patterns, which have been shaped by the existing structure and interaction processes characterizing the district in the recent years. Table 4 outlines a distinction of traditional/new actors, activities and resources in place along the dissemination process.

Traditional ID actors have started approaching I4.0, even though with mixed attempts to disseminate related knowledge. On the one hand, large ID firms, such as Biesse and IMAB, pursued I4.0 projects following an "autonomous" approach - with respect to the local technological trajectories and initiatives - already in place before the spreading of I4.0 interest (Belussi and Pilotti, 2002; Morrison, 2008; Belussi and Caloffi, 2018). They have set up relationships with IT partners and universities developing a mix of local and national relationships (Grandinetti, 2011), without an explicit and deliberate "district" horizon in terms of knowledge diffusion. On the other hand, other key traditional actors - knowledge

\begin{tabular}{|c|c|c|c|}
\hline Actors & Activities & Resources & \\
\hline Traditional ID actors & $\begin{array}{l}\text { Traditional dissemination } \\
\text { activities }\end{array}$ & Traditional resources & \\
\hline Large furniture firms & Local business interaction & Financial resources (corporate) & \\
\hline Technology suppliers & Local buzz & Furniture-making knowledge & \\
\hline COSMOB (Technological & External pipelines & Mechanical knowledge & \\
\hline Center) & Workshops/Seminars & IT/digital knowledge & \\
\hline IT suppliers & Training courses & Social ties & \\
\hline \multicolumn{4}{|l|}{ Consulting firms } \\
\hline \multicolumn{4}{|l|}{ Business associations } \\
\hline \multicolumn{4}{|l|}{ Regional government } \\
\hline New actors & New dissemination & New resources & \\
\hline & activities $\ldots$. & & Table 4. \\
\hline Large firms in different & Open Factory initiatives & Financial resources (national and & Diffusion of I 4.0 in \\
\hline $\begin{array}{l}\text { sectors } \\
\text { Network alliances }\end{array}$ & $\begin{array}{l}\text { Industrial PhDs } \\
\text { Multilateral research }\end{array}$ & $\begin{array}{l}\text { regional government programs on } \mathrm{I4.0)} \\
\text { I4.0 technological knowledge }\end{array}$ & the Pesaro ID - \\
\hline Universities & projects & I4.0 managerial knowledge & continuity and \\
\hline Digital innovation hubs & & & innovation in actors, \\
\hline Cluster initiatives & & & activities and \\
\hline (Regional Government) & & & resources \\
\hline
\end{tabular}

Mechanisms of Industry 4.0 knowledge

43 $-1$ 
$\mathrm{CR}$ 31,1

providers, business association and the Regional Government - have been very active in their dissemination effort. Knowledge providers such as Sinergia and COSMOB have attempted to fulfill their "mission" of knowledge providers and gatekeepers (Morrison, 2008; Grandinetti, 2011) since the beginning of I4.0 diffusion in the Pesaro ID. They have actively set up relationships with other local key actors and with partners outside the district (Molina-Morales et al., 2002; Belso-Martinez et al., 2018). In this respect, they have been able to maintain and consolidate a central role in the local innovation setting both as providers and brokers of knowledge (Molina-Morales et al., 2002; Grandinetti, 2011; Belso-Martinez et al., 2018). Sinergia has been able to integrate business-related and technological knowledge while implementing consulting services in I4.0, whereas COSMOB has attempted to translate I4.0 opportunities in furniture industry-specific projects, as its FabLab project shows. I4.0 has represented a challenge also for local business associations. Evidence shows a very active behavior by the local business associations in involving local firms - mainly SMEs - through innovative approaches in knowledge dissemination. These attempts have been even more difficult in the light of the long-time decreasing participation of local firms in local business associations, and thus I4.0 has represented an opportunity for local business associations to renew their role in the ID of Pesaro. I4.0 knowledge diffusion has been a strategic goal pursued by the Regional Government, engaged in the promotion of direct regional funding related to I4.0 projects and in the setting up of the DIHs. The institutional setting is still in progress while being embedded in the already existing mix of policy measures and procedures supporting local innovation processes within the smart specialization strategy.

In parallel, new actors have emerged as key players in the ID in relation to I4.0 knowledge diffusion processes: large firms operating in different sectors, network alliances promoted by local ID firms, local formal clusters, newly established DIHs and universities. Large firms not belonging to the furniture industry - such as Benelli Armi and Schnell have been perceived by both local institutions and firms as key successful examples of I4.0 implementation. This orientation is further promoted by the active behavior of the regional formal clusters led by Cluster Marche, as these collective actors in the digital context tend to be "more cross-sectoral, horizontal and less geographically concentrated" (Götz and Jankowska, 2017, p. 17). Universities have played an increasing role over time in the light of their specialized knowledge about I4.0 technologies (Camuffo and Grandinetti, 2011; Muscio et al., 2012; Capó-Vicedo et al., 2013). The I4.0 challenge has represented a key driver for a higher involvement and integration of local universities into the Pesaro district, if compared to the marginal role played in the past. Universities have been perceived by both institutions and firms as sources of "global pipelines" (Benneworth and Hospers, 2007; Camuffo and Grandinetti, 2011; Muscio et al., 2012; Capó-Vicedo et al., 2013) connected with advanced I4.0 knowledge sources based in Italy and abroad. It seems that cooperation among traditional and new actors in the Pesaro ID is contributing to develop an emerging shared "subidentity" with regard to I4.0 approach and technologies (Hervas-Oliver et al., 2019), as it is promoted actively by local gatekeepers engaged in I4.0-related knowledge translation as Sinergia and COSMOB.

The increased complexity of the networks of actors has implied a shift and upgrading in the nature of dissemination activities concerning I4.0 knowledge: traditional initiatives such as workshops, courses and formal/informal business interactions - have been integrated by "collective" projects (Fornahl et al., 2015; Hervas-Oliver et al., 2019), such as the Open Factory initiatives, the industrial $\mathrm{PhD}$ positions financed by the Regional Government and the multilateral research projects involving firms, collective actors and institutions of the ID and of the Marche Region. An innovative form of knowledge diffusion 
is the "Open Factory" approach, implemented by the local Industrial Business Association and by Cluster Marche. It represents a form of "organized buzz," being a deliberate and planned attempt to foster informal interaction among firms, universities and institutions (Belussi and Sedita, 2012). Collective actors engage in organizing the initiative, whereas the provision of the knowledge content and the interaction is mainly left to voluntary participants, willing to experience knowledge contamination and search for potential knowledge providers, such as consulting firms, technology centers and universities. An important role is played by the social underpinnings of the project, promoting on the one hand social recognition for innovative firms, entrepreneurs and managers, on the other hand igniting emulation by participants (Staber, 2009; Camuffo and Grandinetti, 2011).

The upgrading of dissemination activities has been driven by the combination of high complexity of I4.0 knowledge - requiring complementary capabilities, notably technological and managerial capabilities and aggregation of a variety of actors (Coletti, 2010; Belussi and Sedita, 2012) - and the financial support and tax incentives provided by the national and regional governments - pushing large firms to undertake large-scale R\&D projects and SMEs to approach in the majority of cases the first steps of the digitalization process (Hervas-Oliver et al., 2019). Funding by the National and Regional Government has been crucial for raising interest by local institutions and firms and for implementing the first R\&D projects in the I4.0 context. Therefore, the monetary dimension is a key factor for explaining ID-based processes concerning I4.0 (Perna et al., 2015). Another relevant factor is the degree of absorptive capacity of local ID firms and institutions (Cohen and Levinthal, 1990; Giuliani, 2005; Camuffo and Grandinetti, 2011). On the one hand, universities in the first place and pioneering firms - large companies and knowledge providers - have been increasingly aware of the I4.0 opportunities and implications and had already previous knowledge of the benefits and challenges of digitalization processes. On the other hand, institutions, business associations and local firms mainly SMEs - have suffered initially their limited knowledge about I4.0 and have attempted to fulfill this gap through participation to training initiatives and hiring qualified personnel. It could be argued that, overall, the knowledge brokering effort has been initially impaired by the limited awareness and knowledge about I4.0 technological and managerial opportunities and challenges (Mittal et al., 2018).

In synthesis, this research shows that in the furniture ID of Pesaro the dissemination of I4.0 knowledge has been characterized by three main interrelated patterns. First, the horizon of I4.0 upgrading - in terms of focal actors, main activities and key resources - shows blurred boundaries in terms of sectors and geographic location (Götz and Jankowska, 2017). Most of the dissemination activities involve firms active in different sectors and have a regional dimension, as ID firms and institutions have attempted to search for I4.0 expertise in closer geographical areas. Second, the I4.0 diffusion shows a fragmentation of initiatives of both firms and institutions; some firms - mainly large sized - have often pursued autonomous paths involving selected partners (Belussi and Pilotti, 2002; Morrison, 2008; Belussi and Caloffi, 2018), whereas institutions, public bodies and business associations show both cooperative and competitive behavior, because of the conflicting objectives of diffusing a complex type of knowledge - leading to institutional collaboration - and searching for financial resources - leading to increased competition. This fragmentation is shaped, on the one hand, by the reduced intensity of social ties experienced in the ID community in the recent years, and, on the other hand, by the "explorative" orientation of the various ID actors engaged in knowledge search. Moreover, the analysis of Pesaro ID shows the lack of a specific policy/program targeting the ID as such, as instead other studies on I4.0 diffusion in traditional IDs have shown (Hervas-Oliver et al., 2019). Third, the diffusion of I4.0 knowledge - characterized by high complexity and by the integration of
Mechanisms of Industry 4.0 knowledge 
$\mathrm{CR}$ 31,1

technological and managerial knowledge (Alberti and Pizzurno, 2015) - pushed ID firms and institutions to pursue deliberate structured initiatives - allowing for informal and formal interactions (Belussi and Sedita, 2012; Lazzeretti and Capone, 2016) - which in various instances implied the experimentation of new interaction processes, leading to innovative forms of "collective" cooperation (Leckel et al., 2020).

\section{Conclusions}

This paper presents and discusses an in-depth empirical research over the diffusion of I4.0related knowledge in the Pesaro ID in Italy active in a traditional industry such as the furniture sector. This research contributes to the literature on innovation in IDs and clusters on two interrelated grounds.

First, it provides further research on I4.0 and IDs and clusters (Götz and Jankowska, 2017; Hervas-Oliver et al., 2019), developing an in-depth analysis of the variety of knowledge dissemination processes - where both institutions and firms are involved - mapped through the ARA framework able to highlight key actors, activities and resources (Håkansson and Snehota, 1995). Notably, our study on the traditional Pesaro ID points out three main patterns:

(1) the horizon of I4.0 upgrading shows blurred boundaries in terms of sectors - firms active in different sectors are involved - and geographic location, reaching the regional dimension;

(2) the fragmentation of I4.0 diffusion in terms of initiatives and projects by both firms and institutions; and

(3) the pursuit of deliberate and structured initiatives allowing for experimentation of new interaction processes, combining formal and informal exchanges (Belussi and Sedita, 2012; Lazzeretti and Capone, 2016; Leckel et al., 2020).

Second, this paper contributes to the stream of research on knowledge creation and diffusion in IDs and clusters, providing empirically based insights over emerging local learning processes in IDs (Belussi and Pilotti, 2002; Camuffo and Grandinetti, 2011; Belussi and Sedita, 2012; Bocconcelli et al., 2015). Notably, the forms of "collective cooperation" in I4.0 projects represent innovative mechanisms linking traditional ID actors to technologically advanced firms and organizations, fostering open localized learning and exploiting localized social ties. These "collective" mechanisms could represent one key driver to renew the cooperative interaction in IDs and clusters (Hervas-Oliver et al., 2019) and promote local initiatives inspired to "open innovation" logics (Leckel et al., 2020), pushed by the selfinterest of those local firms available to commit time and resources (Munksgaard and Medlin, 2014) to improve their absorptive capacity to join and exploit "selected" business networks within and outside the ID (Belussi and Sedita, 2012). Each initiative could be considered as a "temporary resource constellation and activity pattern in which the actors form a distinct logic and develop new solutions in relation to each other" (Ingemansson Havenvid et al., 2016, p. 86). The analysis of innovative knowledge diffusion projects linking ID/cluster studies and the IMP business network perspective - could therefore contribute to the emerging conceptual debate on "temporary spatial clusters" (Palmer et al., 2017).

This research has obviously limitations. First, the empirical analysis concerns the initial phase of the spreading of I4.0-related knowledge in the Pesaro ID, which is still undergoing. Therefore, this paper provides insights over in-progress processes and does not provide a complete ex-post analysis. Second, the main goal is the mapping of the variety of 
dissemination processes; therefore, the in-depth analysis of specific initiatives is out of the scope of this paper.

The phenomenon of I4.0 adoption in IDs and clusters deserves further empirical research and conceptual development. Future research could focus on specific and interconnected aspects that have been pointed out in this paper: the trajectory of specific I4.0 technologies, the nature and features of key dissemination activities, the role played by new actors. Future studies could examine more in depth the dissemination of knowledge of specific I4.0 technologies, such as IoT, AI and collaborative robotics, whose diffusion and Mechanisms of Industry 4.0 knowledge implementation in industrial clusters might follow different trajectories (Cucculelli and Lena, 2017; Ingaldi and Ulewicz, 2019; Ivanov et al., 2020) and concern different types of actors and dissemination mechanisms. Furthermore, additional research is needed on the implementation of key I4.0 projects and initiatives - courses, $\mathrm{PhD}$ programs, bilateral and multilateral R\&D projects and regional programs - in IDs and their underlying interaction processes - whose features might generate different kinds of knowledge diffusion processes - in line with recent research (Götz and Jankowska, 2017; Hervas-Oliver et al., 2019). Finally, future contributions on this phenomenon could explore the role of the main actors, with a focus on those emerging firms and organizations - including collective actors (Hervas-Oliver et al., 2019) - playing an innovative role in the I4.0 diffusion, such as formal clusters, universities (Benneworth and Hospers, 2007) and ad hoc organizations such as DIHs.

The empirical research undertaken in this paper has various managerial implications. First, IDs and cluster firms should pay attention to the selection process of I4.0 knowledge providers. Local knowledge brokers could provide assistance in fostering contacts with potential partners based both inside and outside the cluster (Molina-Morales et al., 2002; Belso-Martinez et al., 2018). Dissemination activities in the ID could represent useful opportunities for networking with potential partners and for assessing the adequate type of investment in technology and organizational innovations. Second, the evaluation and adoption of I4.0 technologies is a complex process which requires establishing relationships also with universities, to develop R\&D projects, to hire qualified personnel and to address effectively both the technological and managerial challenges of I4.0. Local universities might represent adequate partners for ID firms - especially SMEs - if appropriate interaction mechanisms are in place, thus reducing the "cognitive" distance between them (de Zubielqui et al., 2015). Third, firms in traditional IDs are required to invest in human resources to evaluate and exploit I4.0 technologies. While firms active in high-tech clusters might have a stronger cognitive proximity with I4.0-related technologies (Götz and Jankowska, 2017), traditional cluster firms require strengthening their absorptive capacity to interact with key actors, both inside and outside the cluster (Becattini and Rullani, 1996; Camuffo and Grandinetti, 2011; Belussi and Sedita, 2012). Pursuing I4.0 trajectories in IDs requires "talent" in addition to technologies (Salter et al., 2000). Investment in human resources could concern upgrading technical/IT functions, introducing hybrid positions such as Innovation Managers and setting up industrial $\mathrm{PhD}$ positions in cooperation with universities.

This research has also relevant policy implications. I4.0 technologies could represent a key driver for renewal of traditional IDs (Hervas-Oliver et al., 2019) in terms of technological upgrading and localized interaction patterns. This could not be easy in the light of their increasingly fragmented setting in terms of business networks and social ties. First, institutions need to be well-equipped in terms of I4.0 awareness and knowledge to plan and coordinate effective dissemination activities. This research has shown that coordination of dissemination activities could be impaired and slowed down by the limited expertise on I4.0 of institutions and organizations promoting them. Second, previous knowledge of the existing needs by local 
$\mathrm{CR}$ 31,1

businesses and of the actual interaction patterns over I4.0 in the local ID (Eklinder-Frick, 2016) could make policy measures better "nested" in the ID networks and more effective in their implementation (Hoholm and Araujo, 2017), thanks to the combination of "constructed networks" and "emerging networks" (Rubach et al., 2017). As Rubach et al. (2017, p. 179) argue, "there is a need to disrupt what is already happening, and at the same time mobilise support for the "new" element from the existing actors." This could help in avoiding fragmentation - and the related frictions - in the institutional effort, using efficiently the resources available and selecting the most appropriate dissemination mechanisms, thus leading to more effective "informal district networking" (Belussi and Sedita, 2012). Stronger cooperation with local universities and business associations could be useful in this regard (Camuffo and Grandinetti, 2011; Muscio et al., 2012; Capó-Vicedo et al., 2013). Universities - in the light of their specialized I4.0 knowledge and neutral role in the eye of local stakeholders - could be placed at the core of the main dissemination projects. The involvement of firms and organizations active in I4.0 technologies could provide opportunities to plan and launch "local open innovation" projects (Leckel et al., 2020) by local institutions able to promote interaction processes based on "collective cooperation." Finally, it should be highlighted that the key driver for most of the ID actors - besides the pioneering role of some large firms and institutions - has been the monetary incentive offered by the National Government and implemented by the Regional Government through its funding initiatives. The economic incentive is important, but it should not be de-coupled by the promotion of awareness of I4.0 benefits through appropriate dissemination activities; otherwise, ID firms would risk adopting new technologies without a clear business/product strategy. The provision of financial assistance should be characterized by a careful and fine-grained evaluation of the quality and goals of I4.0 projects proposed by ID firms and by continuity in the medium-long term, to support the required technological and organizational transformation.

\section{References}

Alberti, F.G. and Pizzurno, E. (2015), "Knowledge exchanges of innovation networks: evidences from an Italian aerospace cluster", Competitiveness Review, Vol. 25 No. 3, pp. 258-287.

Albino, V., Garavelli, A.C. and Schiuma, G. (1999), "Knowledge transfer and inter-firm relationships in industrial districts: the role of the leader firm", Technovation, Vol. 19 No. 1, pp. 53-63.

AmCham (American Chamber of Commerce in Italy) (2018), "Il futuro di industry 4.0 in Italia", Industrial report.

Arnold, C., Kiel, D. and Voigt, K.I. (2016), "How the industrial internet of things changes business models in different manufacturing industries", International Journal of Innovation Management, Vol. 20 No. 8, pp. 1640015.

Balland, P.A., Belso-Martínez, J.A. and Morrison, A. (2016), "The dynamics of technical and business knowledge networks in industrial clusters: embeddedness, status, or proximity?", Economic Geography, Vol. 92 No. 1, pp. 35-60.

Barrett, M., Davidson, E., Prabhu, J. and Vargo, S.L. (2015), "Service innovation in the digital age: key contributions and future directions", MIS Quarterly, Vol. 39 No. 1, pp. 135-154.

Bathelt, H., Malmberg, A. and Maskell, P. (2004), "Clusters and knowledge: local buzz, global pipelines and the process of knowledge creation", Progress in Human Geography, Vol. 28 No. 1, pp. 31-56.

Becattini, G. (1990), "The Marshallian industrial districts as a socioeconomic notion", in Pike, F. and Becattini, G. (Eds), Industrial Districts and Inter-Firm Cooperation in Italy, International Institute for Labour Studies (ILO), Geneva, pp. 37-51.

Becattini, G. (1991), "Italian industrial districts: problems and perspectives", International Studies of Management and Organization, Vol. 21 No. 1, pp. 83-90. 
Becattini, G. and Rullani, E. (1996), "Local systems and global connections: the role of knowledge", in Cossentino, F. Pyke, F. and Sengenberger, W. (Eds), Local Regional Response to Global Pressure: The Case of Italy, International Institute for Labour Studies (ILO), Geneva, pp. 159-174.

Belso-Martinez, J.A., Diez-Vial, I., Lopez-Sanchez, M.J. and Mateu-Garcia, R. (2018), "The brokerage role of supporting organizations inside clusters: How does it work?”, European Planning Studies, Vol. 26 No. 4, pp. 706-725.

Belussi, F. and Caloffi, A. (2018), "The role of leading firms in explaining evolutionary paths of growth: Italian and Turkish clusters on the move", in Belussi, F. and Hervas-Oliver, J.L. (Eds), Agglomeration and Firm Performance, Springer, Cham, pp. 155-188.

Belussi, F. and Pilotti, L. (2002), "Knowledge creation, learning and innovation in Italian industrial districts", Geografiska Annaler: Series B, Human Geography, Vol. 84 No. 2, pp. 125-139.

Belussi, F. and Sedita, S.R. (2009), "Life cycle vs. multiple path dependency in industrial districts", European Planning Studies, Vol. 17 No. 4, pp. 505-528.

Belussi, F. and Sedita, S.R. (2012), "Industrial districts as open learning systems: combining emergent and deliberate knowledge structures", Regional Studies, Vol. 46 No. 2, pp. 165-184.

Benneworth, P. and Hospers, G.J. (2007), "The new economic geography of old industrial regions: universities as global-local pipelines", Environment and Planning C: Government and Policy, Vol. 25 No. 6, pp. 779-802.

Biggiero, L. (2006), "Industrial and knowledge relocation strategies under the challenges of globalization and digitalization: the move of small and medium enterprises among territorial systems", Entrepreneurship and Regional Development, Vol. 18 No. 6, pp. 443-471.

Bocconcelli, R. (2004), Value Network se Canali di Marketing, Edizioni Goliardiche, Trieste.

Bocconcelli, R., Grandinetti, R. and Tunisini, A. (2015), "Made in Italy: the Italian contribution to the development of business marketing discipline and practices", Journal of Business-to-Business Marketing, Vol. 22 No. 3, pp. 161-196.

Boix, R. and Galletto, V. (2009), "Innovation and industrial districts: a first approach to the measurement and determinants of the I-district effect", Regional Studies, Vol. 43 No. 9, pp. 1117-1133.

Boschma, R.A. and Ter Wal, A.L.J. (2007), "Knowledge networks and innovative performance in an industrial district: the case of a footwear district in the South of Italy", Industry and Innovation, Vol. 14 No. 2, pp. 177-199.

Brancati, R. and Maresca, A. (2017), "Industria 4.0 in Italia: Diffusione, tendenze e qualche riflessione", MET 2017-2018, Industrial report.

Brozzi, R., Pasetti Monizza, G. and Rauch, E. (2018), "Fraunhofer Italia: Laboratorio digitale. Relazione finale sulle attività svolte nell'ambito del progetto laboratorio digitale [CIG: 74179058D9]', Industrial Report.

Calignano, G., Fitjar, R.D. and Kogler, D.F. (2018), "The core in the periphery? The cluster organization as the Central node in the Apulian aerospace district", Regional Studies, Vol. 52 No. 11, pp. 1490-1501.

Camuffo, A. and Grandinetti, R. (2011), "Italian industrial districts as cognitive systems: are they still reproducible?", Entrepreneurship and Regional Development, Vol. 23 Nos 9/10, pp. 815-852.

Capó-Vicedo, J., Molina-Morales, F.X. and Capó, J. (2013), "The role of universities in making industrial districts more dynamic. A case study in Spain”, Higher Education, Vol. 65 No. 4, pp. 417-435.

Carbonara, N. (2004), "Innovation processes within geographical clusters: a cognitive approach", Technovation, Vol. 24 No. 1, pp. 17-28.

Cavana, R.Y., Delahaye, B.L. and Sekaran, U. (2001), Applied Business Research: Qualitative and Quantitative Methods, John Wiley and Sons, Queensland.

Chiarvesio, M., Di Maria, E. and Micelli, S. (2010), "Global value chains and open networks: the case of Italian industrial districts”, European Planning Studies, Vol. 18 No. 3, pp. 333-350. 
CR 31,1

Cohen, W.M. and Levinthal, D.A. (1990), "Absorptive capacity: a new perspective on learning and innovation”, Administrative Science Quarterly, Vol. 35 No. 1, pp. 128-152.

Coletti, M. (2010), “Technology and industrial clusters: How different are they to manage?”, Science and Public Policy, Vol. 37 No. 9, pp. 679-688.

Corò, G. and Grandinetti, R. (1999), "Evolutionary patterns of Italian industrial districts", Human Systems Management, Vol. 18 No. 2, pp. 117-129.

Cucculelli, M. and Lena, D. (2017), "Tecnologie digitali e sistema produttivo. Prime evidenze per le Marche", Journal of Applied Economics, Vol. 36 No. 2, pp. 36-62.

De Marchi, V. and Grandinetti, R. (2016), "Industrial districts evolving in global value chains: evidence from the Italian wine industry", Piccola Impresa/Small Business, Vol. 1, pp. 10-36.

De Marchi, V., Di Maria, E. and Gereffi, G. (Eds). (2017), Local Clusters in Global Value Chains: Linking Actors and Territories through Manufacturing and Innovation, Routledge, London and New York, NY.

De Michele, C., Foresti, G. and Intesa Sanpaolo (2019) "L'imbottito di Forlì e le cucine di Pesaro: la sfida della crescita", Industrial report.

de Zubielqui, G.C., Jones, J., Seet, P.S. and Lindsay, N. (2015), "Knowledge transfer between actors in the innovation system: a study of higher education institutions (HEIS) and SMES”, Journal of Business and Industrial Marketing, Vol. 30 Nos 3/4, pp. 436-458.

Dei Ottati, G. (1994), "Cooperation and competition in the industrial district as an organization model", European Planning Studies, Vol. 2 No. 4, pp. 463-483.

Digital 360 Research - IBM (2017), "Industria 4.0 in Italia: Vision, execution e progettualità", Industrial Report.

Dubois, A. and Gadde, L.-E. (2002), "Systematic combining: an abductive approach to case research", Journal of Business Research, Vol. 55 No. 7, pp. 553-560.

Eder, J. (2019), "Innovation in the periphery: a critical survey and research agenda", International Regional Science Review, Vol. 42 No. 2, pp. 119-146.

Eklinder-Frick, J.O. (2016), “Clustering or interacting for knowledge?”, IMP Journal, Vol. 10 No. 2, pp. 221-242.

Fabbrica Futuro (2018), "La svolta digitale di Benelli armi. Sistemi and impresa (Nov-Dec)", 42-44, available at: www.fabbricafuturo.it/la-svolta-digitale-di-benelli-armi/

Fitzgerald, M., Kruschwitz, N., Bonnet, D. and Welch, M. (2014), "Embracing digital technology: a new strategic imperative”, MIT Sloan Management Review, Vol. 55 No. 2, pp. 1-12.

Fornahl, D., Hassink, R. and Menzel, M.P. (2015), "Broadening our knowledge on cluster evolution”, European Planning Studies, Vol. 23 No. 10, pp. 1921-1931.

Frank, A.G., Mendes, G.H.S., Ayala, N.F. and Ghezzi, A. (2019), "Servitization and industry 4.0 convergence in the digital transformation of product firms: a business model innovation perspective", Technological Forecasting and Social Change, Vol. 141, pp. 341-351.

Giuliani, E. (2005), "Cluster absorptive capacity: why do some clusters forge ahead and others lag behind?”, European Urban and Regional Studies, Vol. 12 No. 3, pp. 269-288.

Giuliani, E. and Bell, M. (2005), "The micro-determinants of meso-level learning and innovation: evidence from a Chilean wine cluster", Research Policy, Vol. 34 No. 1, pp. 47-68.

Götz, M. and Jankowska, B. (2017), "Clusters and industry 4.0-do they fit together?”, European Planning Studies, Vol. 25 No. 9, pp. 1633-1653.

Grandinetti, R. (2011), "Local/global cognitive interfaces within industrial districts: an Italian case study”, The Learning Organization, Vol. 18 No. 4, pp. 301-312.

Håkansson, H. and Snehota, I. (1995), Developing Relationships in Business Networks, Routledge, London.

Håkansson, H., Ford, D., Gadde, L.E., Snehota, I. and Waluszewski, A. (2009), Business in Networks, Wiley, Chichester. 
Halinen, A. and Törnroos, J.A. (2005), "Using case methods in the study of contemporary business networks", Journal of Business Research, Vol. 58 No. 9, pp. 1285-1297.

Hein, A., Weking, J., Schreieck, M., Wiesche, M., Böhm, M. and Krcmar, H. (2019), "Value co-creation practices in business-to-business platform ecosystems", Electronic Markets, Vol. 29 No. 3, pp. 503-518.

Hervas-Oliver, J.L. and Albors-Garrigos, J. (2009), "The role of the firm's internal and relational capabilities in clusters: when distance and embeddedness are not enough to explain innovation", Journal of Economic Geography, Vol. 9 No. 2, pp. 263-283.

Hervas-Oliver, J.L. and Albors-Garrigos, J. (2014), “Are technology gatekeepers renewing clusters? understanding gatekeepers and their dynamics across cluster life cycles", Entrepreneurship and Regional Development, Vol. 26 Nos 5/6, pp. 431-452.

Hervas-Oliver, J.L., Albors-Garrigos, J., de-Miguel, B. and Hidalgo, A. (2012), “The role of a firm's absorptive capacity and the technology transfer process in clusters: How effective are technology centres in low-tech clusters?", Entrepreneurship and Regional Development, Vol. 24 Nos 7/8, pp. 523-559.

Hervas-Oliver, J.L., Albors-Garrigos, J., Estelles-Miguel, S. and Boronat-Moll, C. (2018), "Radical innovation in Marshallian industrial districts", Regional Studies, Vol. 52 No. 10, pp. 1388-1397.

Hervas-Oliver, J.L., Estrelles-Miguel, S., Mallol-Gasch, G. and Boix-Palomer, J. (2019), “A place-based policy for promoting industry 4.0: the case of the castellon ceramic tile district", European Planning Studies, Vol. 27 No. 9, pp. 1838-1856.

Hervas-Oliver, J.L., Gonzalez, G., Caja, P. and Sempere-Ripoll, F. (2015), "Clusters and industrial districts: Where is the literature going? Identifying emerging sub-fields of research", European Planning Studies, Vol. 23 No. 9, pp. 1827-1872.

Hoholm, T. and Araujo, L. (2017), "Innovation policy in an interacted world-the critical role of context", in Håkansson, H. and Snehota, I. (Eds), No Business is an Island: Making Sense of the Interactive Business World, Emerald Group Publishing, Bingley, pp. 105-121.

Horváth, D. and Szabó, R.Z. (2019), "Driving forces and barriers of industry 4.0: Do multinational and small and medium-sized companies have equal opportunities?", Technological Forecasting and Social Change, Vol. 146, pp. 119-132.

Ingaldi, M. and Ulewicz, R. (2019), "Problems with the implementation of industry 4.0 in enterprises from the SME sector", Sustainability, Vol. 12 No. 1, pp. 1-18.

Ingemansson Havenvid, M., Håkansson, H. and Linné, Å. (2016), "Managing renewal in fragmented business networks", IMP Journal, Vol. 10 No. 1, pp. 364-389.

Ingstrup, M.B. (2013), "Facilitating different types of clusters", Management Review, Vol. 24 No. 2, pp. 133-150.

Intesa Sanpaolo (2018), "Economia e finanza dei distretti industriali. Rapporto annuale numero 11", Industrial report.

Ivanov, I., Lukyanova, T. and Orlova, L. (2020), "Digitalization as a driver of innovation for industrial enterprises”, IOP Conference Series: Material Science and Engineering, Vol. 753 No. 8, pp. 1-13.

Kagermann, H., Helbig, J., Hellinger, A. and Wahlster, W. (2013), "Recommendations for implementing the strategic initiative INDUSTRIE 4.0: securing the future of German manufacturing industry", final report of the Industrie 4.0 Working Group, Forschungsunion, Frankfurt/Main.

La Rocca, A., Hoholm, T. and Mørk, B.E. (2017), "Practice theory and the study of interaction in business relationships: some methodological implications", Industrial Marketing Management, Vol. 60, pp. 187-195.

Lazzeretti, L. and Capone, F. (2016), "How proximity matters in innovation networks dynamics along the cluster evolution. A study of the high technology applied to cultural goods", Journal of Business Research, Vol. 69 No. 12, pp. 5855-5865.

Lazzeretti, L., Sedita, S.R. and Caloffi, A. (2014), "Founders and disseminators of cluster research", Journal of Economic Geography, Vol. 14 No. 1, pp. 21-43.

Mechanisms of Industry 4.0 knowledge 
CR 31,1

Leckel, A., Veilleux, S. and Dana, L.P. (2020), "Local open innovation: a means for public policy to increase collaboration for innovation in SMEs", Technological Forecasting and Social Change, Vol. 153, pp. 119891.

Maghssudipour, A., Lazzeretti, L. and Capone, F. (2020), " The role of multiple ties in knowledge networks: complementarity in the Montefalco wine cluster", Industrial Marketing Management.,

Marshall, A. (1920), Principles of Economics, Mcmillan, London.

Maskell, P. (2001), "Towards a knowledge-based theory of the geographical cluster", Industrial and Corporate Change, Vol. 10 No. 4, pp. 921-943.

Mitchell, R., Boyle, B., Burgess, J. and McNeil, K. (2014), "You can't make a good wine without a few beers: gatekeepers and knowledge flow in industrial districts", Journal of Business Research, Vol. 67 No. 10, pp. 2198-2206.

Mittal, S., Khan, M.A., Romero, D. and Wuest, T. (2018), "A critical review of smart manufacturing and industry 4.0 maturity models: implications for small and medium-sized enterprises (SMEs)", Journal of Manufacturing Systems, Vol. 49, pp. 194-214.

Molina-Morales, F.X. (2002), "Industrial districts and innovation: the case of the Spanish ceramic tiles industry", Entrepreneurship and Regional Development, Vol. 14 No. 4, pp. 317-335.

Molina-Morales, F.X., López-Navarro, M.Á. and Guía-Julve, J. (2002), "The role of local institutions as intermediary agents in the industrial district", European Urban and Regional Studies, Vol. 9 No. 4, pp. 315-329.

Moodysson, J. (2008), "Principles and practices of knowledge creation: on the organization of 'buzz' and 'pipelines' in life science communities", Economic Geography, Vol. 84 No. 4, pp. 449-469.

Morrison, A. (2008), "Gatekeepers of knowledge within industrial districts: Who they are, how they interact”, Regional Studies, Vol. 42 No. 6, pp. 817-835.

Müller, J.M., Buliga, O. and Voigt, K.I. (2018), "Fortune favors the prepared: how SMEs approach business model innovations in industry 4.0", Technological Forecasting and Social Change, Vol. 132, pp. 2-17.

Munksgaard, K.B. and Medlin, C.J. (2014), "Self-and collective-interests: using formal network activities for developing firms' business”, Industrial Marketing Management, Vol. 43 No. 4, pp. 613-621.

Muscio, A., Quaglione, D. and Scarpinato, M. (2012), "The effects of universities' proximity to industrial districts on university-industry collaboration”, China Economic Review, Vol. 23 No. 3, pp. 639-650.

Musso, F. (2000), "Economie distrettuali e canali di distribuzione all'estero. Varietà di percorsi delle imprese pesaresi del mobile", INS-EDIT, Genova.

Öberg, C. (2012), "Using network pictures to study inter-organisational encounters", Scandinavian Journal of Management, Vol. 28 No. 2, pp. 136-148.

Osservatorio Industria 4.0 (2018), "Industria 4.0. Produrre, migliorare, innovare”, Industrial report.

Palmer, M., Medway, D. and Warnaby, G. (2017), "Theorizing temporary spatial clusters and institutional boundary-work in industrial marketing", Industrial Marketing Management, Vol. 61, pp. 104-113.

Parrilli, M.D. (2009), "Collective efficiency, policy inducement and social embeddedness: Drivers for the development of industrial districts”, Entrepreneurship and Regional Development, Vol. 21 No. 1, pp. 1-24.

Pereira, A.C. and Romero, F. (2017), "A review of the meanings and the implications of the industry 4.0 concept”, Procedia Manufacturing, Vol. 13, pp. 1206-1214.

Perna, A., Baraldi, E. and Waluszewski, A. (2015), "Is the value created necessarily associated with money? On the connections between an innovation process and its monetary dimension: the case of Solibro's thin-film solar cells", Industrial Marketing Management, Vol. 46, pp. 108-121.

Pietrobelli, C. and Rabellotti, R. (2004), "Upgrading in clusters and value chains in Latin America: the role of policies", Sustainable Development Department Best Practices Series, Inter American Development Bank, Washington, DC, D.C. 
Porter, M.E. (1998), "Clusters and the new economics of competition”, Harvard Business Review, Vol. 76 No. 6, pp. 77-90.

Quintens, L. and Matthyssens, P. (2010), "Involving the process dimensions of time in case-based research”, Industrial Marketing Management, Vol. 39 No. 1, pp. 91-99.

Ramos, C. and Ford, D. (2011), "Network pictures as a research device: developing a tool to capture actors' perceptions in organizational networks", Industrial Marketing Management, Vol. 40 No. 3, pp. 447-464.

Roblek, V., Meško, M. and Krapež, A. (2016), “A complex view of”, Sage Open, Vol. 6 No. 2, pp. 1-11.

Rubach, S., Hoholm, T. and Håkansson, H. (2017), "Innovation networks or innovation within networks", IMP Journal, Vol. 11 No. 2, pp. 178-206.

Salter, A., D’Este, P., Pavitt, K., Scott, A., Martin, B., Geuna, A., Nightingale, P. and Patel, P. (2000), "Talent, not technology: the impact of publicly funded research on innovation in the UK", Science Policy Research Unit, University of Sussex, Sussex.

Samarra, A. and Belussi, F. (2006), "Evolution and relocation in fashion-led Italian districts: evidence from two case-studies", Entrepreneurship and Regional Development, Vol. 18 No. 6, pp. 543-562.

Sklyar, A., Kowalkowski, C., Sörhammar, D. and Tronvoll, B. (2019b), "Resource integration through digitalisation: a service ecosystem perspective", Journal of Marketing Management, Vol. 35 Nos 11/12, pp. 974-991.

Sklyar, A., Kowalkowski, C., Tronvoll, B. and Sörhammar, D. (2019a), "Organizing for digital servitization: a service ecosystem perspective”, Journal of Business Research, Vol. 104, pp. 450-460.

Speldekamp, D., Saka-Helmhout, A. and Knoben, J. (2020), "Reconciling perspectives on clusters: an integrative review and research agenda", International Journal of Management Reviews, Vol. 22 No. 1, pp. 75-98.

Staber, U. (2009), "Collective learning in clusters: Mechanisms and biases", Entrepreneurship and Regional Development, Vol. 21 Nos 5/6, pp. 553-573.

Staber, U. and Sautter, B. (2011), "Who are we, and do we need to change? Cluster identity and life cycle", Regional Studies, Vol. 45 No. 10, pp. 1349-1361.

StartUp Grind (2018), "Paolo Viti (Benelli armi SpA) e Mario Moroni (OkNetwork) a Urbino”, available at: www.startupgrind.com/events/details/startup-grind-ancona-presents-paolo-viti-benelli-armispa-e-mario-moroni-oknetwork-a-urbino/

Waxell, A. and Malmberg, A. (2007), "What is global and what is local in knowledge-generating interaction? The case of the biotech cluster in Uppsala", Entrepreneurship and Regional Development, Vol. 19 No. 2, pp. 137-159.

Wolfe, D. and Gertler, M. (2004), "Clusters from the inside and out: Local dynamics and global linkages”, Urban Studies, Vol. 41 Nos 5/6, pp. 1071-1093.

Yin, R.K. (2003), Case Study Research: Design and Method, 3rd ed., Sage, Thousand Oaks.

\section{Further reading}

Kagermann, H., Lukas, W. and Wahlster, W. (2011), "Industrie 4.0: mit dem internet der dinge auf dem weg zur 4. industriellen revolution”, VDINachrichten, Vol. 13, pp. 2.

\section{Corresponding author}

Roberta Bocconcelli can be contacted at: roberta.bocconcelli@uniurb.it

For instructions on how to order reprints of this article, please visit our website:

www.emeraldgrouppublishing.com/licensing/reprints.htm

Or contact us for further details: permissions@emeraldinsight.com 